\title{
Application of Transperineal and Transabdominal Ultrasonography in the Repair of Distal Vaginal Atresia: A Report of Three Cases
}

Şener GEZER ${ }^{a}$,

(D) Hüseyin $\mathrm{KIYAK}^{\mathrm{b}}$

aDepartment of Obstetrics and Gynecology, Kocaeli University Faculty of Medicine,

Kocaeli, TURKEY

bDepartment of Obstetrics and Gynecology, Kanuni Sultan Süleyman Training and

Research Hospital,

İstanbul, TURKEY

Received: 18.12.2018

Received in revised form: 18.03.2019

Accepted: 19.03.2019

Available online: 29.03 .2019

Correspondence:

Şener GEZER

Kocaeli University Faculty of Medicine,

Department of Obstetrics and Gynecology, Kocaeli, TURKEY

dr.senergezer@gmail.com

This study was presented as an oral presentation in 16th Turkish National Obstetrics and Gynecology Congress, May 09-13, 2018, Antalya, Turkey.

For the video of the article:

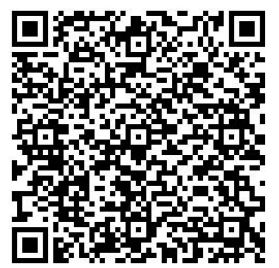

Copyright $\odot 2019$ by Türkiye Klinikleri

\begin{abstract}
Distal vaginal atresia is one of the rare Mullerian anomalies and may often be misdiagnosed as an imperforate hymen. This paper reports pre-operative and intra-operative use of ultrasonography in three patients with distal vaginal atresia. Two patients underwent pull-through surgery and in the other patient, a neovagina was formed using skin graft as the proximal vagina was found to be insufficient for a pull-through vaginoplasty. Pre-operative transperineal ultrasonography and intra-operative transabdominal ultrasonography may prove to be useful in surgical planning and choosing the proper surgical procedure. It also helps prevent damage to adjacent tissues.
\end{abstract}

Keywords: Distal vaginal atresia; transabdominal ultrasonography; transperineal ultrasonography; surgical repair; surgical treatment

$\square$ istal vaginal atresia describes the failure of interaction between the urogenital sinus and the lower part of the vagina. Commonly, the upper part of the vagina, cervix, and uterus are anatomically normal; however, the lower part is closed by fibrous tissue and there will be a small dimple at the vaginal introitus instead of hymen. ${ }^{1}$ Ultrasound and pelvic magnetic resonance imagining help in making the diagnosis. ${ }^{2}$ The measurement of distance between the distal part of the vagina and the perineum by transperineal ultrasonography is important in choosing a suitable treatment option. In addition, intra-operative transabdominal ultrasonography may offer a safer surgical intervention.

This paper reports the usefulness of transperineal and transabdominal ultrasonography in the diagnosis and surgical treatment of three patients with distal vaginal atresia.

\section{CASE REPORT}

\section{CASE 1}

A 12-year-old girl with Down's syndrome presented to the clinic with pelvic pain. She reported that her menstruation cycle had not yet begun. Physical examination revealed that the patient had Tanner stage- 3 breast and pubic hair development. Pelvic examination revealed a closed introitus. Urethra, labia majora, and labia minora appeared normal and the case was misdiag- 


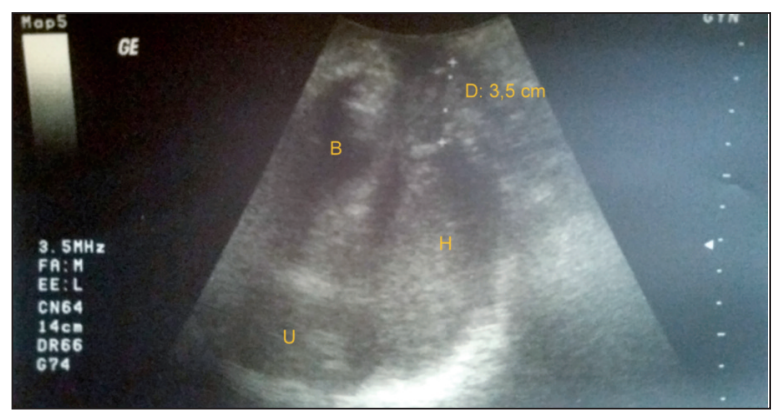

FIGURE 1: Transperineal ultrasound view of case 1 (B: Bladder, $\mathrm{H}$ : Hematocolpos, U: Uterus, D: Distance between the distal part of the vagina and perineum).

nosed to be that of an imperforate hymen. Transperineal ultrasound revealed $5 \times 5 \mathrm{~cm}$ hematocolpos and minimal hematometra (Figure 1). The fibrous tissue between the lower part of the vagina and perineum was measured to be approximately $3.5 \mathrm{~cm}$ in the sagittal view. No additional urogenital anomaly was detected in the radiological studies. After a horizontal hymenal incision was made, blunt dissection through the lower part of vaginal tissue was performed under transabdominal ultrasonic guidance. Though the hematocolpos was drained through the vagina, the vaginal mucosa was not long enough to provide a tension-free anastomosis at the perineum and hence pullthrough vaginoplasty could not be performed. Yet, due to the unplanned events, necessary equipment for a skin graft procedure was not prepared beforehand and therefore an 18F Foley catheter was inserted through the vagina to enable fluid drainage and prevent labial adhesions.

Four weeks later, the authors collaborated with plastic surgeons and created a distal neovagina using a full-thickness groin skin graft. The graft was applied over a $9 \times 2.5 \mathrm{~cm}$ polyamide mold and was fixed to the upper vagina and perineum using 4-0 vicryl sutures. A topical antibiotic cream was applied over the mold and kept in place for six days post-operatively. Self-application and removal of the mold were taught to the patient. After one year follow-up period, sufficient vaginal lumen was obtained. There was no stricture formation and normal, spontaneous menstrual period had started after that time.
CASE 2

A 13-year old girl complaining of abdominal pain was admitted to the hospital. Past medical history of the patient revealed that she had never experienced menstruation before. Physical examination revealed closed introitus; however, the urethra, labia majora, and minora appeared normal. Transperineal ultrasound revealed $4 \times 5 \mathrm{~cm}$ hematocolpos and minimal hematometra (Figure 2). The fibrous tissue between the lower part of the vagina and perineum was measured to be $2 \mathrm{~cm}$ in the sagittal view. The Magnetic Resonance Imaging (MRI) did not find any additional urogenital anomalies.

Blunt dissection was performed through the site of hymenotomy to reach the distal end of the vagina under ultrasonographic guidance. The hematocolpos was evacuated, vaginal mucosa was pulled down and anastomosed to the hymen; the mold prepared from a condom was placed for the prevention of fibrous tissue formation. The patient had normal menstruation at one-year follow-up.

\section{CASE 3}

A 12-year-old girl with a history of primary amenorrhea reported to the clinic. Physical examination revealed normal external genitalia, except a closed introitus. Minimal hematocolpos $(2 \times 3 \mathrm{~cm})$ was detected on transperineal ultrasonographic examination and the distance between introitus and the distal vaginal end was measured to be $1.3 \mathrm{~cm}$. Radiological imaging confirmed the absence of any additional urogenital anomaly. Ultrasonography-guided the distal vaginal tip and pull-through surgery was performed. Since the hymeneal opening was suffi-

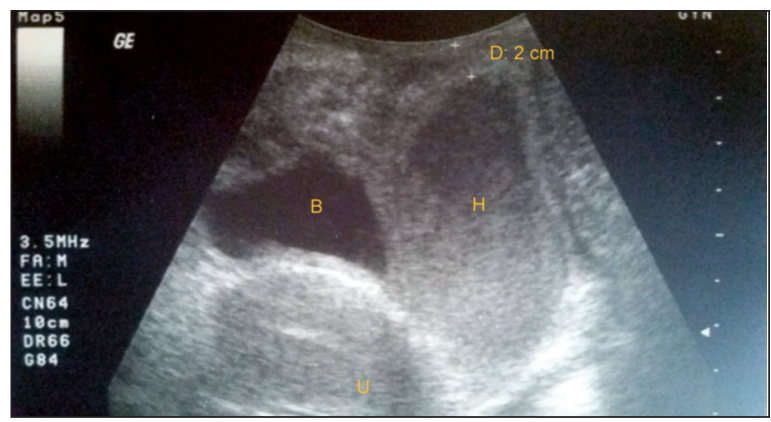

FIGURE 2: Transperineal ultrasound view of case 2 (B: Bladder, $\mathrm{H}$ : Hematocolpos, $\mathrm{U}$ : Uterus, D: Distance between the distal part of the vagina and perineum). 


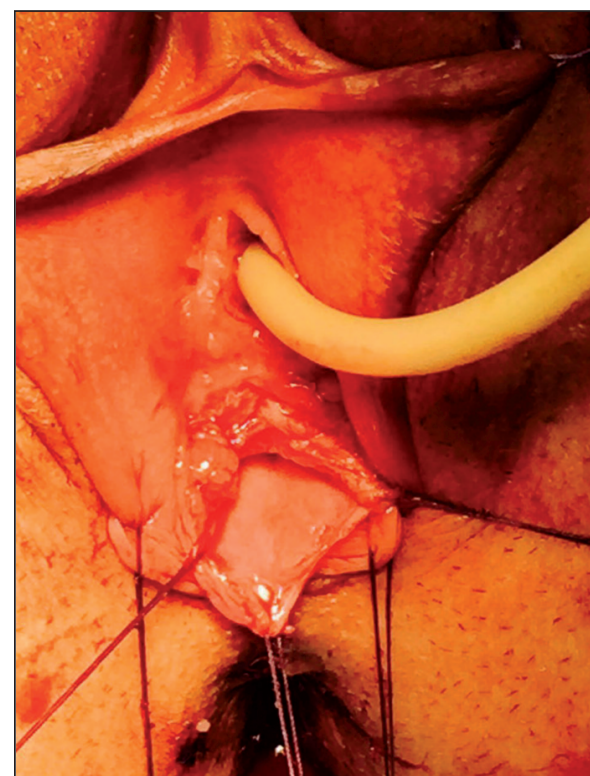

FIGURE 3: Intraoperative view of case 3.

cient enough in this patient, the mold was not inserted (Figure 3). The patient reported normal menstruation within the first year of follow-up.

Note: All the three patients belonged to class IA category for American Society for Reproductive Medicine (ASRM) classification sytem and UOCOV4 for The European Society of Human Reproduction and Embryology (ESHRE) and the European Society for Gynaecological Endoscopy (ESGE) classification systems.,

Informed consent was obtained from all patients in this study.

\section{DISCUSSION}

Distal vaginal atresia is a rare Mullerian anomaly. It represents a lack of interaction between the urogenital sinus and the lower vagina. ${ }^{5}$

Differential diagnoses of distal vaginal atresia may include Mayer Rokitansky Kuster Hauser (MRKH) syndrome or vaginal outlet obstruction due to the transverse vaginal septum at a distal level or an imperforate hymen. In the latter two, surgical excision of the relatively thin septum or hymen sufficiently treats the condition.

Various repair methods have been reported for these anomalies, which include the creation of a neovagina from skin grafts, labial, and introital skin flaps, vaginal dilators, and local pull-through vaginoplasty when the distance of agenesis is $2 \mathrm{~cm}$ or less. ${ }^{6}$ Mansouri reported the formation of a vaginal stricture in 1 out of 16 patients with distal vaginal atresia while carrying out a retrospective evaluation. The average distance from perineum to the level of obstruction was observed to lie between 1.84 and $1.2 \mathrm{~cm}$. Various authors have reported that the presence of more than $3 \mathrm{~cm}$ of the atretic segment posed the patients at an increased risk for vaginal stricture formation, despite the postoperative use of vaginal stents. ${ }^{7}$ In the first case reported in this paper, an atretic segment was greater than $3 \mathrm{~cm}$, and the patient was misdiagnosed to have an imperforate hymen, thus vaginal reconstruction was performed using a skin graft. Fortunately, no stricture formation occurred. In the other two patients, pull-through surgery was performed successfully.

Even though Magnetic Resonance Imagining (MRI) is the gold standard method for the evaluation of Mullerian anomalies, the use of ultrasonography in the diagnosis and treatment of distal vaginal agenesis has been described in the literature. ${ }^{8,9}$ Transperineal ultrasonography measured the atretic segments to be $3.5 \mathrm{~cm}, 2 \mathrm{~cm}$, and $1.3 \mathrm{~cm}$, respectively, in the three cases reported in this paper. Transperineal ultrasonography provided adequate insight into the surgical planning in these three cases. Additionally, transabdominal ultrasonography helped the authors perform a safer surgical procedure, preventing the possible bladder and rectal injury. Although intraoperative use of ultrasonography for Mullerian anomalies has been defined in the literature, only one report has been published regarding ultrasonographic guidance in distal vaginal atresia. ${ }^{8,10-12}$ Intraoperative use of ultrasonography may also reduce morbidity by preventing simultaneous abdominal surgery. A combined abdominal (via laparotomy or laparoscopy) and perineal surgical approach may be used to clarify the anatomy additionally, and aid in proximal vaginal dissection. ${ }^{13,14}$

To the best knowledge of the authors, Down's syndrome has not been associated with distal vaginal agenesis. However, the literature reports only 
one case where it has been associated with a transverse vaginal septum. ${ }^{15}$

In conclusion, the measurement of the distance between the distal vaginal tip and the introitus by transperineal ultrasonography may be useful in choosing a proper surgical procedure. If the distance is greater than $3 \mathrm{~cm}$, the pull-through technique may not be successful since mobilization of vaginal edges to the perineum may not be possible and therefore the use of skin grafts or flaps for surgical treatment may be more appropriate. Nikolaev used an $\mathrm{H}$-shaped incision for perineum and Uflaps for vagina in cases of high atresia. ${ }^{16}$

The use of intra-operative transabdominal ultrasonography is effective in preventing damage to the adjacent tissues, thus helping in reaching the distal vaginal tip securely. The patients with distal vaginal atresia are at an increased risk for postoperative stenosis, infection, graft failure, fistula formation, and damage to surrounding structures, thus necessitating re-surgery.

Supporting Video 1. Aspiration of hematocolpos under guidance transabdominal ultrasound.

\section{Acknowledgments}

The authors thank Yiğit Çakıroğlu for language editing of the manuscript.

\section{Source of Finance}

During this study, no financial or spiritual support was received neither from any pharmaceutical company that has a direct connection with the research subject, nor from a company that provides or produces medical instruments and materials which may negatively affect the evaluation process of this study.

\section{Conflict of Interest}

No conflicts of interest between the authors and / or family members of the scientific and medical committee members or members of the potential conflicts of interest, counseling, expertise, working conditions, share holding and similar situations in any firm.

\section{Authorship Contributions}

Idea/Concept: Şener Gezer, Design: Şener Gezer, Control/Supervision: Şener Gezer, Hüseyin Kıyak, Data Collection and/or Processing: Şener Gezer, Hüseyin Klyak, Analysis and/or Interpretation: Şener Gezer, Hüseyin Klyak, Literature Review: Şener Gezer, Writing the Article: Şener Gezer, Critical Review: Şener Gezer, References and Fundings: Şener Gezer, Materials: Şener Gezer, Hüseyin Kıyak.

\section{REFERENCES}

1. Breech LL, Laufer MR. Müllerian anomalies. Obstet Gynecol Clin North Am. 2009;36(1):4768. [Crossref] [PubMed]

2. Hugosson $\mathrm{C}$, Jorulf $\mathrm{H}$, Bakri $\mathrm{Y}$. MRI in distal vaginal atresia. Pediatr Radiol. 1991;21(4): 281-3. [Crossref]

3. The American Fertility Society. The American Fertility Society classifications of adnexal adhesions, distal tubal occlusion, tubal occlusion secondary to tubal ligation, tubal pregnancies, mullerian anomalies and intrauterine adhesions. Fertil Steril. 1988;49(6):944-55. [Crossref]

4. Grimbizis GF, Gordts S, Di Spiezio Sardo A, Brucker S, De Angelis C, Gergolet M, et al. The ESHRE/ESGE consensus on the classification of female genital tract congenital anomalies. Hum Reprod. 2013;28(8):2032-44. [Crossref] [PubMed] [PMC]

5. Miller RJ, Breech LL. Surgical correction of vaginal anomalies. Clin Obstet Gynecol. 2008;51(2):223-36. [Crossref] [PubMed]

6. Khunda SS, Al-Omari S. A new approach in the management of lower Mullerian atresia. J Ob- stet Gynaecol. 1998;18(6):566-8. [Crossref] [PubMed]

7. Mansouri R, Dietrich JE. Postoperative course and complications after pull-through vaginoplasty for distal vaginalatresia. J Pediatr Adolesc Gynecol. 2015;28(6):433-6. [Crossref] [PubMed]

8. Kresowik J, Ryan GL, Austin JC, Van Voorhis BJ. Ultrasound-assisted repair of a unique case of distal vaginal agenesis. Fertil Steril. 2007;87(4):e976.e9-12. [Crossref] [PubMed]

9. Meyer WR, McCoy MC, Fritz MA. Combined abdominal-perineal sonography to assist in diagnosis of transverse vaginal septum. Obstet Gynecol. 1995;85(5 Pt 2):882-4. [Crossref]

10. Edwards-Freeman C, Amin HK, Abiri M, Giustino PB. The use of intraoperative ultrasonography in the surgical correction of a transverse vaginal septum. J Clin Ultrasound. 1991;19(1):48-50. [Crossref] [PubMed]

11. Wu HM, Huang HY, Lee CL, Soong YK. Laparoscopic ultrasonography for uterovaginal canalization of a didelphic uterus with agenetic cervix. J Am Assoc Gynecol Laparosc. 2002;9(3):376-9. [Crossref]

12. Ludwin A, Ludwin I, Bhagavath B, Martins WP Lindheim SR. Virginity-sparing management of blind hemivagina in obstructed hemivagina and ipsilateral renal anomaly syndrome. Fertil Steril. 2018;110(5):976-78. [Crossref] [PubMed]

13. Ciftci I. Laparoscopic-assisted perineal pullthrough vaginoplasty. J Pediatr Surg. 2012;47(4):e13-5. [Crossref] [PubMed]

14. van Bijsterveldt $C$, Willemsen $W$. Treatment of patients with a congenital transversal vaginal septum or a partial aplasia of the vagina. The vaginal pull-through versus the push-through technique. J Pediatr Adolesc Gynecol. 2009;22(3):157-61. [Crossref] [PubMed]

15. Quinn T, Erickson V, Knudson MM. Down's syndrome, precocious puberty, and transverse vaginal septum: an unusual cause of abdominal pain. J Pediatr Surg. 2001;36(4):641-3. [Crossref] [PubMed]

16. Nikolaev VV, Bizhanova DA. Perineal reconstruction in girls with high vaginal atresia. $J$ Urol. 1998;159(6):2140-2. [Crossref] 